\title{
Veterinary surgeons' legal obligations in sales-related animal health status examinations
}

\author{
ANDRZEJ DZIKOWSKI \\ Department of Pathophysiology, Forensic Veterinary Medicine and Administration, \\ University of Warmia and Mazury in Olsztyn, Oczapowskiego 13, 10-719 Olsztyn, Poland
}

\section{Dzikowski A.}

\section{Veterinary surgeons' legal obligations in sales-related animal health status examinations}

\section{Summary}

The article presents, interprets, analyzes and examines legal obligations of veterinary surgeons who conduct animal examinations, issue decisions on animal health, and prepare opinions in connection with the contract of sale. It examines responsibilities originating from various sources and forming a complex system of relationships. A veterinary surgeon has numerous obligations in the field of civil law (including general civilian rules and norms of the law of obligations) and corporate law (including ethics and professional deontology). Moreover, he also has specific documentation, information, and explanatory duties closely related to the contract. The liability threshold of a veterinary surgeon is very low, which applies in particular to the mixed contract discussed here (an obligation of due diligence in relation to examination and an obligation of result in relation to decision-making).

Keywords: veterinary medicine, civil law, professional ethics, obligation

The performance of sales-related examinations and issuing health status decisions is part of the professional practice of veterinary surgeons.

A medical veterinary examination in connection with a contract of sale is aimed at determining the health status of the animal being sold. It should report whether it is healthy, whether its qualities are as agreed by the parties, and whether it is possible to use it for the purpose intended by the parties to the contract, in particular by the buyer (35). It makes it possible to state whether the animal is sick, whether it has a physical defect, and when this defect occurred. The more defects and diseases are detected during the veterinary examination, the lower the contract-and-investment risk for both parties of the sale. This risk, however, cannot be completely eliminated $(1,2,20,21,23,25,30,44)$.

This examination may have numerous additional functions $(2,6,13,21,44)$, such as being a decisive factor; being a precedent or resolving condition; defining the rights and obligations of the parties; determining the value of the animal, allowing the seller to obtain a price adequate to the quality; being a marketing instrument $(6,21,23)$; determining whether there is any warranty liability for physical defects and to what extent; indicating a fraudulent breach of contract; determining the scope of claims and the percentage decrease in the value of the animal due to a defect; providing evidence $(6,23)$, etc.

The aim of the study was to analyze and discuss legal and ethical-legal obligations of veterinary surgeons, and to propose a new dimension of the model of obligations in sales-related veterinary examinations.

\section{Material and methods}

Juristic analysis and interpretation of legal and ethical provisions $(8,40-42)$ were carried out to determine the legal nature and scope of ex lege and contractual obligations belonging to the veterinary service in question. Linguistic, systematical, functional, teleological, historical, and comparative methods were used.

\section{Results and discussion}

Basic concepts. In the author's opinion, to analyze and interpret the obligation in question, it is necessary to distinguish between three crucial institutions: veterinary medical examination, veterinary decision, and veterinary opinion.

The term examination (Pol. badanie) denotes checking the animal's health status through, at least, a full clinical examination. In most cases, additional tests, 
such as blood tests or diagnostic imaging tests (e.g. $\mathrm{X}$-ray, MRI), are used. The scope of examination includes the analysis and interpretation of test results and the animal's medical history based on the current veterinary knowledge.

The term decision (Pol. orzeczenie) is a comprehensive verdict on the animal's health status, including the animal's level of development, diseases, defects, etc., based on the tests performed. It refers only to the status praesens at the time of testing and issuing a judgment (35).

According to the author, the concept of opinion (Pol. opinia) should refer only to the final formulation of observations and conclusions regarding the animal's health. Thus, it is the way of summarizing and presenting the decision and premises that led to it. The opinion is usually a written certificate. It may, however, be presented in any form. In the case of a veterinarian acting on the basis of a contract, it is a private expert opinion in a broad, factual and functional, sense, rather than in a narrow, strictly procedural, sense.

The legal nature of the veterinarian's obligation is difficult to determine definitively and unequivocally. It has not been accomplished either in the veterinary scientific literature, or in legal doctrine and jurisprudence.

Statutory acts $(41,42)$ contain broad concepts of veterinary services and veterinary professional performance. These provisions directly indicate that the examination of animals and the issuing of decisions on their health status are veterinary services and a form of professional conduct $(41,42)$.

The veterinary surgeon's obligation is qualified as an obligation to act diligently, an obligation of result, or a mixed obligation. These different qualifications affect the specification of the duties of the veterinarian performing the examination and his potential liability for breach of contract $(1,2,6,13,15,16,18,25,27$, $29,33-35,44,45)$.

The first (minority) model is based on an analogy to veterinary diagnostics and therapy $(6-8,11,13,16,22$, $31,44)$ and focuses mainly on the stage of clinical and additional tests. The second, dominant, model focuses on drawing up a written opinion $(1,2,4,6,8,11,13$, $15,16,18,25-27,29,31-35,44)$.

The author rejects these models and adopts a third, holistic model of classification (27). It assumes that the examination part of service should be assessed in terms of diligence, and the decisive part in terms of the result. It should be noted that, according to the author, it is the passing of the decision, and not the writing of the opinion, that is the main component of the veterinarian's service and his major obligation in this case. It is the most adequate model. It is well-suited to the borderline nature of the veterinarian's contractual obligations.
This model of classification lends itself to an unambiguous application of medical law regarding the requirements of due diligence, compliance with legal norms and acting lege artis $(4,11,13,16,24,43,44)$. At the same time, it makes it possible to assess the decision as work, the consequences of which are subject to the (analogous) warranty liability and damages of the warranty regime $(8,27)$. It ensures a much more effective protection of the contracting party (the seller or buyer of the animal) $(8,27)$.

Types of duties. Determining the duties of veterinary surgeons performing sales-related examinations is extremely difficult because of their multifaceted nature and various origins of these examinations. The following origins of duties can be derived and distinguished: universal and confessional ethical norms, being a citizen (subject to constitution, statutory acts), being a party to civilian contracts (need of compliance with international, EU and national regulations, including general norms of the civil law, general clauses of diligence, norms related to a specific type of contract, warranty, guarantee and liability for damages, etc.), running a business, being an employer or employee, being liable for performing the duties of an expert, being a veterinarian.

Obligations arising from various spheres are mixed. Interpenetration can be found in ethics (general human rules, religious norms, the constitution, general clauses of civil law, corporate code of ethics, etc.) or informational duties (EU law, national civil law, corporate ethical and deontological rules, etc.).

The author considers it pointless to separate these spheres, because only their combined application and examination can provide a full picture of obligations resting on the veterinary surgeon - and this is not tantamount to a simple summary approach to individual norms considered separately.

Along with the growing number of veterinary examinations analyzed here, especially in Germany, with regard to horses $(24,29)$, exact rules for professional conduct of veterinary surgeons have been developed and specified. The spread of this institution has led, among others, to the creation of standards that ought to be followed in legal and veterinary terms of due diligence, good veterinary practice $(6,25)$ and proper performance of the obligation. It should be noted that in this case it is possible to properly apply the achievements of human medical law $(11,16)$.

Contract templates, model test protocols and professional guidelines developed by representatives of science and practice, veterinary and breeding associations, or veterinary professional corporations $(1,2$, $13,24,30,32,44)$ provide good practice guidelines and shape the standards of professional conduct and proper performance of obligations. Not only are the 
rules of veterinary medical conduct shaped by such guidelines, but they also influence the specific formulation of civilian legal standards. They influence future patterns and attitudes, improve the quality of services and can be considered as part of the development of both individual veterinary surgeons and the entire professional group.

General obligations. Veterinary practice requires compliance with provisions of universally binding law and corporate law, principles of professional ethics, and rules of professional deontology (40-42). Each veterinary surgeon is obliged to act lege artis (40). This concept should, in the author's opinion, be understood as broadly as possible. It applies to all aspects of the veterinary profession and affects overall obligations arising from the right to practice veterinary medicine.

It should be emphasized that the compliance of actions and decisions with current, up-to-date veterinary knowledge is a crucial element of lege artis practice $(1,11,40)$. Participation in specialization training and scientific conferences, obtaining academic titles, and following scientific journals are examples of continuous professional and scientific development.

Another aspect of the discussed problem is the compliance of all veterinary procedures with legal and ethical standards, such as bona fides, according to various systems of norms $(8,12,40,41)$. This compliance is a key aspect of the due, special, above-average diligence standard that must be met by every veterinary surgeon $(12,16,24,29,38,40,41,43)$.

The public trust character of the veterinary profession and the existence of the professional self-government raises the level of social expectations, required due diligence, ethical conduct, and responsibility $(9$, $10,12,31,38-41,44)$. Veterinary practice is regulated and controlled in terms of both education and the quality of services. The level of due ethical conduct is higher for veterinary surgeons than it is for standard market operators $(12,38,40,41)$.

It should be noted that, according to the author, participation in the bodies of veterinary professional self-government (in particular as a professional liability advocate and a professional judge) does have an impact on tightening the model of required diligence. The holding of other offices in legislation, public administration and higher education, or involvement in social and political activities, etc. could similarly raise the level of required diligence. Professional running a business is also an evident, factor exacerbating the liability $(5,8,27,36,37)$.

For an individual veterinarian, the level of required diligence is also affected by his personal abilities, special skills, above-average qualifications, or extra education (e.g. additional university studies, courses, trainings, seminars and scientific meetings, academic degrees and titles, or specialization training, especially in horse diseases, dog and cat diseases, or veterinary radiology) $(5,27,31,34,35,44)$.

Specific individual patterns of behavior and demeanor can be distinguished. E.g. different patterns ought to be applied to: small-animal practitioner conducting business activity; professor of veterinary medicine; specialist in dog and cat diseases, not conducting business activity; $\mathrm{PhD}$, specialist in veterinary radiology; $\mathrm{PhD}$, specialist in epizootiology and veterinary administration, member of the veterinary professional court, conducting business activity, etc.

Obligations concerning information, documentation, and explanation. Due, above-average diligence in this context is demonstrated not only through the professional competence, skills and knowledge of the veterinary surgeon, his use of appropriate instruments (40), compliance with the law, ethics $(40,41)$, and the contract (8), but also through his fulfillment of obligations including information, documentation, and explanation $(16,24,42,43)$.

Informational duties belong to accessory elements of the veterinary surgeon's obligations arising from different contracts: both sales-related diagnostic services and typical therapeutical services $(6,13,44)$. In this case, the following sources of obligations to explain, provide information and obtain consent can be mentioned:

- firstly, the rules of medical law sensu largissimo - providing information about risk and the course of procedures, obtaining informed consent $(3,4,11,13$, $14,16,17,19,24,28,40,42-44)$;

- secondly, appropriate application of the statutory regulations of the contract of sale, including warranty and consumer rights (8).

Documentation duties related to the contract analyzed here $(6,13,44)$ differ from those in veterinary diagnostic and therapeutic services (6). While in typical therapeutic activities, documentation is only incidental and has an auxiliary role in the proceedings (44), it does have a crucial role in the subject of the current analysis. It can be classified as one of the main obligations of the debtor $(6,13,44)$.

Proper documentation includes truthful, scrupulous, clear and regular recording of the course and results of all actions and procedures. In addition, it is necessary to store the documentation according to the rules of personal data protection and professional secrecy (42). The scope of documentation includes, which is less obvious, the need to make it available to the court, professional self-government bodies, and the animal owner $(6,42,44)$.

The most important part of the contract and a cardinal obligation is to issue a flawless decision and to prepare on its basis a flawless veterinary opinion. 
The opinion is also the most important aspect of documentation, as it summarizes the course and effects of veterinary examinations performed $(2,6,13$, 44). In addition, there is no doubt that the obligation to document the course and results of all veterinary procedures can also be derived from the basic principles of veterinary art, as documentation is one of the chief professional duties of veterinary surgeons $(2,6,11$, $13,40,42)$.

Moreover, veterinary professional rules indicate an integral connection between documentation and professional secrecy (medical confidentiality) (42). According to the systematic interpretation of legal norms, the obligation of professional secrecy may even be regarded as a kind of documentation (a part of the process of creation and storage of documentation). In the author's opinion, however, it is a separate obligation. This is supported by the historical interpretation, as this ethical obligation dates back to ancient times and is included in the Hippocratic Oath. Also the functional and teleological interpretation confirms this view: this obligation is much broader than the problem of documentation itself, it serves much more important purposes and protects more significant legal goods. Confidentiality applies to all information obtained by the veterinarian and his co-workers as part of their professional activities, including those not recorded on any medium.

A new group of duties of the veterinary surgeon performing sales-related tests can be distinguished. It is referred to in the German-language literature as Aufklärungspflichten, i.e. duties of information and explanation. These secondary and mixed obligations resulting directly from the type of contract analyzed here (including general and specific norms of civil law and the need to properly perform the service according to the contract), as well as indirectly from the development of medical veterinary law (professional nature of veterinary services) $(2,11,13,16,24,43,44)$. They extend and deepen the previously existing documentation $(2,11,16,44)$ and information obligations, such as the preliminary interview with the contractor (32). They are an integral part of the contract to examine the animal health status (13).

They complement the achievement of the purpose for which the study is carried out (2) - the decisive process. Unlike typical obligations, such as obtaining informed consent for medical procedures and providing pre-contractual information, they should be performed after the examination, and not as a preparatory step for conducting the tests or concluding the contract. They include provision of in-depth, detailed information about the results obtained and their significance $(6$, $13,31)$. The findings should be explained in a form (written or oral) that is understandable to the lay client and is adapted to his level of knowledge, education, and understanding $(16,44)$.

According to the author, the duties analyzed here do not include the presentation of a prognosis of future development (the worsening of the defect over time) or recommendations for further treatment. There is, however, no consensus in the doctrine $(2,6,13,32)$.

Among the secondary duties of a veterinary surgeon, it is also possible to distinguish the need to exercise proper care as well as the custody and guardianship of the animal during its entire stay in the clinic. Violation of the above-mentioned obligation may result in tort liability $(2,13)$.

As a result of the analysis conducted here, it should be assumed that

- every veterinary surgeon has an above-average, objective standard of diligence due to his being a member of this very profession;

- the liability threshold for a veterinary surgeon is very low - and it decreases with his professional and social development. The higher the professional, scientific and social qualifications and competences or personal abilities of a given veterinarian, the higher the extent of his potential civil and professional liability (the lower the threshold, the stricter and easier to bear the liability is);

- in addition to general obligations (nonspecific and applicable to all veterinary surgeons and all aspects of their work), there are numerous duties of information, explanation, clarification, and documentation that are specific only to the contract examined here.

\section{References}

1. AdamczukF. J. F: Pferdekaufrecht. Rechtgeschichte des Pferdekaufs, geltendes Recht, Perspektiven. Sierke, Hannover 2008, p. 43-45, 109-114, 161, 173.

2. Althaus J., Genn H. J., Harps-Hansen O., Warnebier S.: Die Kaufuntersuchung des Pferdes. Medizinischer und juristischer Leitfaden. Schlütersche, Hannover 2011, p. 9-11, 16-21, 49-95.

3. Ashall V., Millar K. M., Hobson-West P.: Informed Consent in Veterinary Medicine: Ethical Implications for the Profession and the Animal "Patient". Food Eth. 2008, 1, 247-258.

4. Babińska I., Soltyszewski I., Karaźniewicz J., Szarek J., Felsmann M. Z., Dzikowski A.: Veterinary necropsy in the light of ethics and law. Med. Weter. 2019, 75, 652-655.

5. Banaszczyk Z., Granecki P.: O istocie należytej staranności. Palestra 2002, 7-8, 12-29.

6. Bardeleben G. von: Rechtliche Besonderheiten des Pferdekaufs unter besonderer Berücksichtigung der tierärztlichen Kaufuntersuchung. Agricola, Hildesheim 2013, p. 3-4, 171, 179-181, 184-185, 210-216, 223-228.

7. Bemmann K.: Osteochondrose und Kaufuntersuchung aus juristischer Sicht. Recht Landw. 2006, 1, 85-86.

8. Civil Code. Ustawa z dnia 23 kwietnia 1964 r. Kodeks cywilny. Dz. U. 2020, poz. 1740 .

9. Court of Appeal, Cracow. I ACa 124/01. Przegl. Sąd. 2002, 10.

10. Court of Appeal, Łódź. I ACa 1148/12. Lex 1451700.

11. Deutsch E., Spickhoff A.: Medizinrecht. Springer, Berlin-Heidelberg 2014, p. 14-15, 73-118, 261-338, 366-368, 435 ff., 497 ff., 520 ff., 576-614.

12.Dzikowski A.: Przypadki znęcania się nad zwierzętami i reakcji na nie a etyka zawodowa lekarzy weterynarii - wątpliwości etyczno-prawne. Stud. Prawnoustroj. 2020, 47, 35-54.

13. Eichelberg S.: Kaufuntersuchungen beim Pferdekauf. Dr. Kovač, Hamburg 2018, p. 42-140. 
14. Fettman M. J., Rollin B. E.: Modern Elements of Informed Consent for Genera Veterinary Practitioners. JAVMA 2002, 221, 1386.

15. Fikentscher W., Heinemann A.: Schuldrecht. Allgemeiner und besonderer Teil. De Gruyter, Berlin-Boston 2017, p. 723-743.

16. Fink C.: Auklärungspflicht von Medizinalpersonen (Arzt, Zahnarzt, Tierarzt, Apotheker). D-Druck-Spescha, St. Gallen 2008, p. 6-10, 12-15, 85-191, 207-228, 318.

17. Flemming D., Scott J. F.: The Informed Consent Doctrine: What Veterinarians Should Tell Their Clients. JAVMA 2004, 221, 1436.

18. Harke J. D.: Besonderer Schuldrecht. Springer, Berlin-Heidelberg 2011, p. $69-132$.

19. Hernandez E., Fawcett A., Brouwer E., Rau J., Turner P. V.: Speaking up: Veterinary Ethical Responsibilities and Animal Welfare Issues in Everyday Practice. Animals (Basel) 2018, 8.1, 3-22.

20. Kessler Ch.: Der Kauf gebrauchten Waren nach dem Diskussionsentwurf des Schuldrechtsmodernisierungsgesetzes, Z. Rechtspolitik 2001, 34, 70-71.

21. Korth U.: Minderung beim Kauf. Mohr Siebeck, Tübingen 2010, p. 9, 13, 15, $17 \mathrm{ff}, 21 \mathrm{ff}$.

22. Lägel R., Doenecke H., Jakob H., Oppermann Th., Schönberg F.: Der Tierarzt im Recht. Ferdinand Enke, Stuttgart 1938, p. 40-42.

23. Malchow S.: Negative Beschaffenheitsvereinbarungen beim Kauf unter besonderer Berücksichtigung des Gebrauchtwagen- und Pferdekaufs. Peter Lang, Frankfurt (Mein) 2009, p. 66, 79, 114-115.

24. Neuhaus L.: Ursachen für Schadenersatzansprüche gegenüber Tierärzten nach Kaufuntersuchungen beim Pferd - Eine Untersuchung von 189 Schadensfällen aus den Jahren 1978-2005. MBV, Berlin 2007, p. 22-39, 66

25. Neumann L.: Das Pferdekaufrecht nach der Schuldrechtsmodernisierung. Deutsche Reiterliche Vereinigung FN, Berlin 2005, p. 35, 38, 41.

26. Oechsler J.: Vertragliche Schuldverhältnisse. Mohr Siebeck, Tübingen 2017, p. 805-881.

27. Osajda K. (ed.): Komentarze prawa prywatnego. Kodeks cywilny. Komentarz. C. H. Beck, Warszawa 2017, IIIA, p. 79-96, IIIB, p. 296-298, 302-305, 317, 350-357.

28. Passantino A., Quartarone V., Russo M.: Informed consent in veterinary medicine: Legal and medical perspectives in Italy. O. J. Anim. Sci. 2011, 1, 128-134.

29. Reichert F. Tierarzt und Pferdekauf. Universität, Gießen 1994, p. 18.

30. Riedel B. M.: Pferde im Verbrauchsgüterkauf. Sachmängel und Beweislastumkehr nach $\S 476$ BGB. Shaker, Aachen 2007, p. 158-159.
31. Rosbach P., Weiß Ch., Meyer K., Hillebrand Ch.: Pferderecht. Ein Handbuch für Pferdekäufer (...) und Tierärzte. C. H. Beck, München 2018, p. 128, 134, $138,146,151-166$

32. Salis B., von (ed.): Ankaufsuntersuchung beim Pferd. Gustav Fischer, JenaStuttgart 1996, p. 29 ff., 39 ff., 45, 59 ff., 56-128.

33.Schmidt-Räntsch J., Maifeld J., Meier-Göring A., Röcken M.: Das neue Schuldrecht. Einführung - Texte - Materialien. BGB, EGBGB, UKlaG, BGBInfoV. Bundesanzeiger, Köln 2001-2002, p. 34 ff.

34. Schulze E.: Die zivilrechtliche Haftung des Tierarztes. Universität, Berlin 1991, p. $11,15$.

35. Sommer M.: Der Pferdekauf. Universität Münster 2000, p. 69, 85, 89.

36. Sośniak M.: Cywilnoprawna ocena staranności zawodowej. N. Prawo 1980, 2, 21-23.

37. Sośniak M.: Umowy o świadczenie usług z art. 750 kodeksu cywilnego. PiP 1981, 5, 61-73.

38. Supreme Court of Poland. III CZP 84/12. OSN-IC 2013, 7-8.

39. Szymański J. Z.: Samorządność zawodów zaufania publicznego w społeczeństwie obywatelskim, [in:] Samorząd zawodowy w demokratycznym państwie prawa. Kancelaria Senatu RP, Warszawa 2014, p. 21-26, 160-165.

40. Veterinary Surgeons' Ethical Code. Kodeks Etyki Lekarza Weterynarii Uchwała nr 3/2008/VII Nadzwyczajnego VII Krajowego Zjazdu Lekarzy Weterynarii.

41. Veterinary Surgeons' Profession and Veterinary Chambers Act. Ustawa z dnia 21 grudnia 1990 r. o zawodzie lekarza weterynarii i izbach lekarskoweterynaryjnych, Dz. U. 2016, poz. 1479; 2018, poz. 1669; 2019, poz. 577.

42. Veterinary Surgical Practice Act. Ustawa z dnia 18 grudnia 2003 r. o zakładach leczniczych dla zwierząt, Dz. U. 2019, poz. 24.

43. Werres R.: Aufklärungspflichten in Schuldverhältnissen und deren Grenzen Universität Köln 1985, p. 139 ff., 142 ff.

44. Wolkowski B.: Die rechtliche Behandlung der Kaufuntersuchung beim Pferdekauf. Dr. Kovač, Hamburg 2010, p. 27-28, 34-51, 53, 55, 62-100, 110 , 129-142, 181-198, 200, 204-205, 244-245, 313-355.

45. Wójcik S.: Odgraniczenie umowy o dzieło od umowy o pracę i umowy zlecenia Z. Nauk. UJ. Pr. Prawn. 1963, 10, 165-194

Corresponding author: Andrzej Dzikowski, LLM, DVM, Department of Pathophysiology, Forensic Veterinary Medicine and Administration, University of Warmia and Mazury in Olsztyn, Oczapowskiego 13, 10-719 Olsztyn, Poland; e-mail: andrzej.dzikowski@uwm.edu.pl 